\title{
Legal Convergence in Building Asymmetric Decentralization Models for Accelerating Regional Development
}

\author{
Malicia Evendia \\ Constitutional Law \\ Lampung University \\ Lampung, Indonesia \\ 0000-0003-0794-3135
}

\author{
Ade Arif Firmansyah* \\ Constitutional Law \\ Lampung University \\ Lampung, Indonesia \\ ade.firmansyah@fh.unila.ac.id
}

\begin{abstract}
This study aims to analyze and offer the concept of legal convergence in the course of building an asymmetric decentralization model in Indonesia. Asymmetric decentralization as a reality that occurs in Indonesia and constitutionally has a foundation, but on the one hand, the State of Indonesia does not yet have a legal format to accommodate the needs, demands, and regional diversity in the practice of implementing asymmetric decentralization in Indonesia. This study uses a normative legal research method with a statutory and conceptual approach. The results of this study indicate that: the implementation of asymmetric decentralization in Indonesia does not yet have a clear legal policy direction. Currently, the regions that have these specialties/privileges each have different arrangements in the administration of their regional government. These various arrangements have a core unit of understanding that can be identified and used as material for the formal legal content of the implementation of asymmetric decentralization in Indonesia. Legal convergence in the regulation of asymmetric decentralization is needed to be used as a legal umbrella that can accommodate the needs and demands of the diversity of regions in Indonesia, and as a process in building a model of asymmetric decentralization in Indonesia.
\end{abstract}

Keywords-asymmetric decentralization; regional autonomy; development; legal convergence

\section{INTRODUCTION}

Decentralization and Regional Autonomy that have taken place since January 2001 are events that have brought about a fundamental change in the relationship between the Central Government and Regional Governments. The relationship that was previously centralized has turned into a decentralized one, which is marked by the granting of broad and real autonomy to the regions. Decentralization is indeed a logical consequence of the emergence of democratic life in Indonesia since the New Order era [1]. The principle of autonomy which forms the basis for regional administration is regulated in Article 18 paragraph (2) of the 1945 Constitution which states that Regional Governments are authorized to regulate and manage their Government Affairs according to the Principles of Autonomy and Co-Administration and are granted the widest possible autonomy. Regional governments, both provinces, districts, and cities, have authority over their regions based on these provisions.

Indonesia is one of the countries that adhere to and recognize asymmetrical decentralization in managing central-regional relations. Asymmetric decentralization within the framework of the Unitary State of the Republic of Indonesia in the form of special regions and special regions is following Article 18B paragraph (1) of the 1945 Constitution. Currently, there are at least 5 (five) regions that are given specialties and privileges by the government, namely the Special Region of Yogyakarta Province, Province of the Special Capital Region of Jakarta, Aceh Province, Papua Province, and West Papua Province. The granting of special autonomy to the region is not without reason. The reasons for giving these specialties/privileges also have different backgrounds.

Special autonomy is one part of the right to selfdetermination. This is recognized as one way to avoid the process of state disintegration. Regions that obtain special autonomy status have exclusivity in the administration of local government.

Giving specificity to the area creates jealousy for other regions. If explored more deeply, the specificity may not only be limited to the five regions, there are still other regions that are also entitled to special status. Soepomo concerning this once said that regional autonomy as a principle means respecting regional life according to history, customs, and characteristics of its own within the framework of a unitary state. Each region has a history and special characteristics that are different from the history and characteristics of other regions [2]. On the other hand, the demand for greater autonomy and including special autonomy also stems 
from the fact that the central government gives too small a share to the regions within the framework of balancing funds, the amount of which is considered disproportionate to the natural wealth or contributions made by the regions concerned to the center [3].

The dilemma of the division of authority or different autonomous portions, known as asymmetric decentralization, has become an interesting study from the legal and development perspective. The exclusive authority of the special autonomous region, on the one hand, creates jealousy in other regions to be able to also have more space in dealing with local government affairs. The law that regulates special autonomy is following the applicable legal principle, namely the lex specialist principle. Thus, all laws and regulations that are regulated differently in Indonesia still follow the special autonomy law. This also causes the division of authority between the central and regional governments, for these special/special regions to be different from other regions that are subject to and refer to the law on regional government symmetrically.

The implementation of asymmetric decentralization is still hampered by regulatory issues. The implementation of symmetrical (uniform) decentralization with the regional autonomy law is since the government does not have an asymmetrical decentralization design to be implemented in the regions. The 1945 Constitution submits/delegates its arrangements to the law. Therefore, each area that is given a special or special status, has a different content and model. This arrangement also proves the flexibility of asymmetric decentralization.

The ongoing conflict in Papua, in this case, indicates that the formal legal regulations governing special autonomy in Papua are not yet accommodating. Papua is an area that has been given special autonomy but is not directly proportional to regional development in Papua. It is not surprising that the number of judicial review cases submitted to the Constitutional Court related to the special autonomy law is Papuan. However, only a few requests were granted by the Constitutional Court. The emergence of the desire for the disintegration of Papua is the impact of the failure to achieve improvements in people's welfare during the granting of special autonomy since 2001 .

This condition shows that there are legal problems that have not been able to accommodate the existing conflicts. This paper attempts to describe and analyze the problems and realities of asymmetric decentralization from the point of view of legal convergence. Indra said convergence is a point of view in drafting laws. Lawmakers must have a comprehensive view.

Convergence is used as an effort to unify legal systems, conceptions, principles, or norms. Convergence is inevitable in the current era of globalization. Lawyers and economists have predicted that the legal order will move in a more adequate direction. They argue that the implications of globalization will force the legal order to converge to achieve economic efficiency.

\section{RESEARCH METHODS}

This research is normative legal research, which examines various laws and regulations that are used as the basis for legal provisions to analyze the direction of asymmetric decentralization policies in Indonesia. The legal research model used is a comprehensive and analytical study of primary legal materials and secondary legal materials. Considering that this research includes normative legal research, the approach in this study uses a statutory approach and a conceptual approach [4]. The data were analyzed qualitatively by describing the data generated from the research into a systematic explanation form so that a clear picture of the problem under study could be obtained, the results of the data analysis concluded deductively.

\section{DISCUSSIONS AND ANALYSIS OF RESULTS}

To understand and answer research problems, the following will be presented in the following subchapters descriptions and analysis.

\section{A. Asymmetric Decentralization within the Unitary State of the Republic of Indonesia}

Indonesia is one of the countries that adhere to the form of a unitary state, this is explicitly regulated in Article 1 paragraph 1 of the 1945 Constitution of the Republic of Indonesia (UUD 1945), which states that "the State of Indonesia is a unitary state, in the form of a republic". According to Abu Daud Busroh, the unitary state has only one government, namely the central government which has the highest power or authority in all fields of government [5]. In a unitary state, there is a principle that all state affairs are not divided between the central government (central government) and local government (local government) in such a way that state affairs in the unitary state remain a unanimity (eenheid) and that the highest power holder in that country is the Central Government [6].

A unitary state can be divided into two forms, namely a unitary state with a centralized system and a unitary state with a decentralized system. In a unitary state with a centralized system, everything in the country is directly regulated and managed by the central government and the regions only need to carry out everything that has been instructed by the central government. Whereas in a unitary state with a decentralized system, regions are given the opportunity and power to regulate and manage their household (regional autonomy) which is called an autonomous region [7].

Indonesia as a unitary state with a decentralized system is explicitly regulated in Article 18 paragraph (2) of the 1945 Constitution, that "provincial, district 
and city governments regulate and manage their government affairs according to the principle of autonomy and co-administration". Furthermore, Article 18 paragraph (5) of the 1945 Constitution also contains a stipulation that "Regional governments exercise the widest possible autonomy, except for government affairs which are determined by law to be the affairs of the Central Government". This provision is further elaborated by Law Number 23 of 2014 concerning Regional Government as last amended by Law Number 9 of 2015 concerning the Second Amendment to Law Number 23 of 2014 concerning Regional Government.

Mohammad Hatta said that the establishment of regional government (autonomous government) is one aspect of the implementation of popular sovereignty (democracy), namely the right of the people to determine their fate not only at the top of the country's leadership but also in every place in cities, villages, and regions. This idea is understandable, considering that Indonesia's very wide geographical condition with its diversity has led to the need to accommodate it in the implementation of decentralization and regional autonomy [8]. This makes it impossible for the (central) government to carry out all government affairs by itself so that the implementation of these affairs is divided into regions based on the principle of autonomy.

Regional governments exercise the widest possible autonomy, except for government affairs which are determined by law to be the affairs of the Central Government (Article 18 paragraph (5) of the 1945 Constitution). Thus the formation of autonomous regions in the context of decentralization in Indonesia has the following characteristics [9]:

- autonomous regions do not have sovereignty or semi-sovereignty like in a federal state;

- decentralization is manifested in the form of submission of government affairs;

- the submission of government affairs as referred to in point $b$ above is mainly related to the regulation and management of the interests of the local community (locality) following their initiative based on the aspirations of the community.

Amendments to the Law on Regional Government through Law no. 23 of 2014 concerning Regional Government as last amended by Law Number 9 of 2015 provide space for regions to develop their territories. The existence of regional autonomy gives rights, authorities, and obligations to autonomous regions to regulate and manage their households.

In essence, the implementation of regional government is a process of governance that is oriented towards accelerating the realization of community welfare through improving services, empowerment, and community participation, as well as increasing regional competitiveness by taking into account the principles of democracy, equity, justice, privileges, and specificity of a region in the state system. Unity of the Republic of Indonesia [10].

The implementation of decentralization requires the division of government affairs between the government and local governments [11]. The division of authority in the administration of central and local governments indicates the relationship between the central and local governments. The relationship between the central and local governments has gone through various models and forms according to the regulations set by the government as the basis for administering government in the regions [12].

Legal policy on decentralization since independence until now continues to experience dynamics. Changes in the laws regarding regional government have an impact on the authority possessed by regions in the implementation of regional autonomy. This portion of regional authority is highly dependent on the policies and political decisions of legislators, in this case, the House of Representatives and the President. Every time the laws and regulations regarding regional government change, the pattern of relations built between the Center and the Regions also changes [13]. This pattern of relations between the center and the regions is the key to synergy and harmonious and harmonious relations between the center and the regions.

According to Bagir Manan, one of the difficulties in fostering harmonious relations between the center and the regions is due to differences in tendencies. In this case, the center is responsible for ensuring the integrity of the unitary state, guaranteeing the same services for all the people of the country (the principle of equal treatment), ensuring the uniformity of actions and arrangements in certain fields (the principle of uniformity), sometimes more inclined to the administration of government. centralized. On the other hand, efforts to realize justice and social welfare are strongly influenced, for example, by the pattern of community structure. The ways of realizing justice and social welfare in a (relatively) homogeneous society will be different from that of a plural society. In a pluralistic society, efforts to realize justice and social welfare must pay attention to the characteristics of the local structure (which are local), differences in culture and belief systems, differences in nature and geographical location, differences in historical backgrounds, and so on. Attention to these differences and specificities further requires that there are differences in services and ways of administering government. This kind of government administration demand is only possible in a decentralized government [14].

Bagir Manan is of the view that decentralization is seen from the relationship between the center and the regions which refers to the 1945 Constitution, then: first, the form of relationship between the center and the 
regions should not reduce the rights of local people to participate (freely) in the administration of local government. Second, the form of relationship between the center and the regions should not reduce the rights of the regional (people) to take the initiative or take initiatives. Third, the form of the relationship between the center and the regions may vary from one region to another. Fourth, the form of relations between the center and the regions are in the context of realizing justice and social welfare in the regions [15]. For this reason, the relationship between the central government and the regions should ideally run in harmony, this is in addition to optimizing the administration of government, it is also to avoid the existence of a separatist movement.

Indonesia is one of the countries that adhere to and recognize asymmetrical decentralization in managing central-regional relations. Decentralization in Indonesia provides room for symmetrical decentralization and asymmetrical decentralization. Symmetrical decentralization is the implementation of decentralization or the same or uniform pattern of relations between the center and the regions as stipulated in Law no. 23 of 2014. Meanwhile, asymmetric decentralization is the existence of specialties or privileges given to several regions. Regions that obtain special autonomy status have exclusivity in the administration of regional government.

Currently, five regions have received asymmetric decentralization. Article 399 of Law no. 23 of 2014, confirms that "The provisions in this Law also apply to the Province of the Special Region of Yogyakarta, the Province of the Special Capital Region of Jakarta, the Province of Aceh, the Province of Papua, and the Province of West Papua, as long as it is not specifically regulated in the Law that regulates the privileges of and the specificity of the area." So that each region has a lex specialize in the administration of regional government.

The law that regulates special autonomy is following the applicable legal principle, namely the lex specialist principle. Thus, all laws and regulations that are regulated differently in Indonesia still follow the special autonomy law. This also causes the division of authority between the central and regional governments, for these special/special regions to be different from other regions that are subject to the regional government law.

The Unitary State of the Republic of Indonesia as regulated in Articles 18A and 18B of the 1945 Constitution does recognize the special status and privileges of a region. Article 18A paragraph (1) states that "The relationship of authority between the central government and provincial, district, and city governments, or between provinces and districts and cities, is regulated by law with due observance of the specificity and diversity of the regions." Furthermore, Article 18B paragraph (1), "The state recognizes and respects special or special regional government units which are regulated by law."

Jimly emphasized that the provisions of Article 18, Article 18A and Article 18B of the 1945 Constitution have changed the format of a rigid unitary state to a dynamic unitary state. First, it is possible to make federalist arrangements in the relationship between the central and local governments. Second, in the dynamics of this relationship, it is also possible to develop a pluralist autonomy policy [16]. This is then elaborated by granting special autonomy or privileges that apply a different pattern of autonomy from other regions or known as asymmetric decentralization policies

\section{B. Relation of Regional Development and Decentralization}

Regional development is a priority in decentralization. The existence of decentralization should also be followed by regional development. The realization of regional development will lead to the welfare of the people. According to Koirudin, the decentralization policy carried out by governments in democratic countries has at least two main benefits, namely [17]:

- Political benefits are aimed at channeling local community political participation as well as in strengthening political stability nationally.

- Administrative and economic benefits, namely to ensure that development has been carried out effectively and efficiently in the regions to improve the welfare of the people there.

Liang Gie also stated the reasons for adopting decentralization, one of which is that from the point of view of the interests of economic development, decentralization is needed because local governments can do more and directly assist the development [18].

Regional development is an activity that takes place continuously and continuously which aims to improve the welfare of the people, both materially and spiritually. And to be able to realize these goals, it is necessary to pay much attention to the problem of development financing [19]. Financing development requires quite a lot of money as an absolute condition for development to be successful [20]. The more available sources of financing, it is hoped that the success of the implementation of regional autonomy will be greater [21].

From a legal perspective, to review the relation between regional development and decentralization, also requires a legal theory of development, as stated by Mochtar Kusumaatmadja. The function of law according to the legal theory of development, in addition to achieving order and justice, also functions as a means of renewal in society. Mochtar Kusumaatmadja argues that change and order (or order) are twin goals of a developing society, law becomes a 
means that cannot be ignored in the development process [22].

Likewise, the existence of Law Number 23 of 2014 concerning Regional Government as the legal basis for symmetrical decentralization in Indonesia, as well as Law Number 21 of 2001 concerning Special Autonomy for the Papua Province in conjunction with Law Number 35 of 2008, Law Number 11 of 20012006 concerning the Government of Aceh, Law Number 29 of 2007 concerning the Provincial Government of the Special Capital Region of Jakarta as the Capital of the Unitary State of the Republic of Indonesia, and Law Number 13 of 2012 concerning the Privileges of the Special Region of Yogyakarta, have a legal function as a means of development. However, in reality, currently, despite more than two decades of decentralization in Indonesia, equitable development has still not been achieved. The existence of high development inequality in Indonesia is a big challenge.

The existence of a decentralization policy with existing regulations has not been able to achieve the goals and benefits of decentralization itself. In this case, the central government plays an important role in overcoming this problem. Each region, which has different characteristics, requires policies that can capture regional dynamics. For this reason, legal convergence in building an asymmetric decentralization model is an alternative policy in overcoming equity and accelerating regional development.

\section{The Concept of Legal Convergence in Building} Asymmetric Decentralization Models in Indonesia

This paper begins with the author's findings that the reality of local governance in Indonesia is still dynamic, both in terms of regulation and practice, and the decentralized system adopted in Indonesia is still looking for an ideal format. Meanwhile, the current polemic of asymmetric decentralization has yet to find a clear path. Each special region in Indonesia has its laws governing the administration of regional government. This paper will describe the concept of "legal convergence" as the basis for regulating asymmetric decentralization in Indonesia.

The meaning of the word convergence can be interpreted as a state towards a meeting point or convergence [23]. Point to a meeting point. Danrivanto, who described the concept of law as a means of community renewal towards the convergence of Information and Communication Technology, revealed that the concept of legal convergence is an effort to form anticipatory laws against the times [24].

Globalization causes the convergence of the legal order or legal system. Lawyers and economists have predicted that the legal order will move in a more adequate direction. They argue that the implications of globalization will force the legal order to converge to achieve economic efficiency. This is because the related regulatory order of a legal order will make one system alone will not be able to provide optimal solutions to the problems that arise [25]. This is based on the argument against functional equivalence, where a legal system can appear different but the difference is only on the surface. Because basically, the institution in question is still able to fulfill the same and similar functions [26].

On the other hand, there is an understanding that legal culture is an obstacle to efforts to converge the legal order [27]. The approach to looking for links with similarities and differences between legal systems, or comparing different legal systems is expected to explain the importance of the concept of legal convergence [28]. The legal concepts of convergence, harmonization, and unification have become concepts that continue to develop.

According to Nuno Garoupa and Anthony Ogus, "Convergence is used to refer to the coming together of legal systems, concepts, principles, or norm; harmonization is seen as an approximation of national or state laws by provisions laid down by laws, regulation, or administrative action; and unification is an extreme version of harmonization in which differentiability or flexibility is ruled out and no derogation in the preempted areas is allowed." [29] The legal concept referred to in general can be understood as contained in the following table [30]:

TABLE I. DIFFERENCES IN THE CONCEPTS OF CONVERGENCE, HARMONIZATION, AND UNIFICATION

\begin{tabular}{|l|l|}
\hline \multicolumn{1}{|c|}{ Legal Concept } & \multicolumn{1}{|c|}{ General Understanding } \\
\hline Convergence & $\begin{array}{l}\text { Used as an effort to unify legal systems, } \\
\text { conceptions, principles, or norms }\end{array}$ \\
\hline Harmonization & $\begin{array}{l}\text { Used as an effort to prepare national laws } \\
\text { or state laws that have regulatory relevance } \\
\text { based on laws, regulations, and } \\
\text { administrative actions }\end{array}$ \\
\hline Unification & $\begin{array}{l}\text { It is used as an extreme harmonization } \\
\text { effort for both differences and flexibility in } \\
\text { arrangements and does not provide room } \\
\text { for other provisions }\end{array}$ \\
\hline
\end{tabular}

Legal experts argue that a legal system is formed based on different formats but still has a core unity of understanding [31].

Asymmetric decentralization in Indonesia is currently only given to five regions, namely Aceh, Papua, West Papua, DKI Jakarta, and the Special Region of Yogyakarta. The legal basis for the regulation of asymmetric decentralization in each of these regions is currently regulated in Law no. 11 of 2006 concerning the Government of Aceh (as the basis for granting the special autonomy status of Aceh Province), Law no. 21 of 2001 concerning Special Autonomy for Papua Province (as the basis for granting special autonomy status for Papua Province), Law no. 35 of 2008 concerning the Stipulation of Government Regulation instead of Law Number 1 of 2008 concerning Amendments to Law Number 21 of 2001 
concerning Special Autonomy for the Papua Province to become a law (as the basis for granting the special autonomy status of West Papua Province after splitting itself from the Province of West Papua). Papua), Law No. 29 of 2007 concerning the Provincial Government of the Special Capital Region of Jakarta as the Capital of the Unitary State of the Republic of Indonesia (as the basis for the specific authority possessed by the Province of DKI Jakarta as the Capital of the Republic of Indonesia), and Law No. 13 of 2012 concerning the Privileges of the Special Region of Yogyakarta. (as the basis of Yogyakarta's privileged status).

Special autonomy for Aceh, Papua, and West Papua was granted for political, economic, and security reasons. Giving special status to Yogyakarta is more for reasons of historical and cultural background. While granting special status to Jakarta because of Jakarta's position not only as an autonomous region but also as the center of government and the nation's capital [32].

Djohermansyah Djohan who is the President of the Institute for Regional Autonomy, Director General of Regional Autonomy 2010-2014, thinks that even though the region has special or special autonomy status, there should be no state within the state, and the welfare of the people must be number one, not the welfare of the elite. Distortions in the management of asymmetrical decentralization in Indonesia can be corrected by improving issues of authority, institutions, finance, Korbin was, politics, and local government.

According to Wehner, asymmetric decentralization based on the background of asymmetrical authority is divided into two. First, political asymmetry is given as a response to diversity and even tension (or conflict) of ethnicity, regional character, religion, and others. Second, administrative asymmetry, which is given based on considerations of efficiency or strengthening the capacity of local governments to carry out administrative and economic activities effectively [33]. The granting of special autonomy to Aceh, Papua, and West Papua is basically to reduce tensions between the central and regional governments which lead to separatism tendencies.

The asymmetric decentralization policy aims to build a democratic, fair and prosperous regional government [34]. The granting of special autonomy to Aceh, Papua, and West Papua is dominated by two factors, political factors, and economic factors. Politically, the purpose of this special autonomy policy is to create a democratic and harmonious government order. Economically, namely to increase economic growth for the welfare of local communities [35]. The opportunities are given to the five regions then gave rise to the same desire to get special or special autonomy status for other regions in Indonesia. One example is Bali.

Constitutionally, the provisions in Articles 18A and 18B of the 1945 Constitution also do not rule out the possibility of granting special autonomy to other regions. The demand for greater autonomy and including special autonomy also stems from the fact that the central government gives too small a share to the regions within the framework of balancing funds, the amount of which is considered disproportionate to the natural wealth or contributions made by the regions concerned to the center [36]. This is then related to the problem of regional development which is still not evenly distributed.

The application of asymmetric decentralization is an appropriate and appropriate thing to continue in the context of government life in Indonesia. This is following the opinion of The Liang Gie which states that each region has a different history and special characteristics than the history and characteristics of other regions. In this regard, the government must keep away from all affairs that intend to unify all regions according to one model [37]. Authority in this regard is one of the important aspects of asymmetric decentralization. Even according to Parolari and Voltmer, the authority that can be exercised independently and effectively is the key to autonomy and is an important element in conflict transformation [38]. This is in line with the opinion of Djohermansyah Djohan which has been described previously that authority is one of the factors that need to be improved in building an ideal asymmetric decentralization model in Indonesia.

Until now, the central government has not set indicators or parameters for a region to obtain special status, even the current asymmetric policy has not been accompanied by a definite legal basis. The dilemma of the division of authority or the different autonomous portions (asymmetric decentralization) becomes an interesting study from the legal and development perspective. This is inseparable from the fact that decentralization should also be followed by regional development. However, in reality, decentralization and regional development have not gone hand in hand, there are still many regions that are left behind.

According to the author, the implementation of asymmetric decentralization is still hampered by regulatory issues. The implementation of symmetrical (uniform) decentralization with the existence of a regional government law indicates that the government does not yet have an asymmetrical decentralization design to be implemented in the regions. Normatively, the 1945 Constitution submits or delegates its arrangements in the form of a law. However, currently, the regulation regarding asymmetric decentralization is only regulated in the laws of each region which are given special or special status, there is no legal umbrella (umbrella act) that generally regulates asymmetric decentralization. It is not surprising that each law that regulates these specialties has different contents and models, and this does not rule out the possibility of injustice in the provision of these specialties. 
On the other hand, the current implementation of asymmetric decentralization still has shortcomings, this can be seen from the improvement in community welfare that has not been fulfilled by several regions that have received special autonomy. The ongoing conflict in Papua indicates that the formal legal regulations governing special autonomy in Papua are still not accommodating. Papua is an area that has been given special autonomy but it is not directly proportional to regional development in Papua [39]. It is not surprising that the number of judicial review cases submitted to the Constitutional Court related to the special autonomy law is Papuan. There are at least eight decisions of the Constitutional Court related to the submission of a Judicial Review on the special autonomy law. However, only a few requests were granted by the Constitutional Court. The emergence of the desire for the disintegration of Papua is the impact of not achieving improvements in community welfare during the granting of special autonomy since 2001 .

Thus, based on what has been described above, according to the author, the implementation of asymmetric decentralization in Indonesia still does not have a format that is following regional conditions and needs and has not been able to overcome the problem of uneven regional development. One of the reasons for this condition is the absence of regulations that serve as the basis and legal legitimacy for the practice of implementing asymmetric decentralization as a whole. The author offers the concept of legal convergence as an umbrella act in implementing a better asymmetric decentralization and being part of the process of building an appropriate asymmetric decentralization model for Indonesia. The central government in this case needs to take legal policies that can accommodate the needs and diversity of different regions in the better practice of implementing asymmetric decentralization.

\section{CONCLUSIONS}

Based on the description described above, it can be concluded that the current practice of asymmetric decentralization does not yet have a clear legal format, both in terms of procedural and substance. The regional diversity in Indonesia, which is not limited to Aceh, Jakarta, Yogyakarta, Papua, and West Papua, is a consideration and the reality is that a strong legal basis is needed to accommodate the demands and needs of the regional diversity in the implementation of asymmetric decentralization. Legal convergence in asymmetric decentralization is an alternative solution to the problems and legal needs needed in building a model of asymmetric decentralization in Indonesia.

\section{REFERENCES}

[1] Ni'matul Huda, in Lukman Santoso Az, (2013). Hukum Pemerintahan Daerah: Mengurai Problematika Pemekaran Daerah Pasca Reformasi di Indonesia, accessed in https://www.researchgate.net/publication/328304969
[2] Abdullah, H. Rozali. (2000). Pelaksanaan Otonomi Luas dan Isu Federalisme Sebagai Alternatif, Jakarta: Raja Grafindo Persada.

[3] Muhammad Habibi \& Erni Zuhriyati, Kecemburuan Daerah Penghasil Setelah Praktek Desentralisasi Asimetris, https://www.researchgate.net/publication/330424411_Kecem buruan_Daerah_Penghasil_Setelah_Praktek_Desentralisasi_A simetris

[4] Peter Mahmud Marzuki, Penelitian Hukum. (Jakarta: Prenada Media, 2005).

[5] Abu Daud Busroh, Ilmu Negara, (Jakarta: Bumi Aksara, 1990), p.64

[6] Ni'matul Huda, Perkembangan Hukum Tata Negara Perdebatan dan Gagasan Penyempurnaan. (Yogyakarta: FH UII Press, 2014). p. 241

[7] Fahmi Amrusyi, "Otonomi Dalam Negara Kesatuan", in Abdurrahman (ed), "Beberapa Pemikiran tentang Otonomi Daerah", (Jakarta: Media Sarana Press, 1987), p.56, in Ni'matul Huda, Desentralisasi Asimetris dalam NKRI: Kajian Terhadap Daerah Istimewaa, Daerah Khusus, dan Otonomi Khusus, (Bandung: Nusa Media, 2014), p.2

[8] Didik Sukriono, Hukum, Konstitusi dan Konsep Otonomi, (Malang: Setara Press, 2013), p.124

[9] Ibid.

[10] General explanation of Law no. 23 Year 2014

[11] Fatkhul Muin, Otonomi Daerah dalam Perspektif Pembagian Urusan Pemerintah-Pemeritah Daerah dan Keuangan Daerah. Fiat Justisia Vol. 8, No.1, Januari-Maret 2014.

[12] Dudung Abdullah, Hubungan Pemerintah Pusat dengan Pemerintah Daerah, Jurnal Hukum Positum Vol.1, No.1, Desember 2016.

[13] Bambang Ariyanto, Pengelolaan Hubungan Pusat dan Daerah dalam Penanganan Pandemi Covid-19, Suloh Jurnal Program Studi Magister Hukum, Edisi Khusus, Oktober 2020, pp.37-57.

[14] Bagir Manan, Hubungan Antara Pusat dan Daerah Menurut UUD 1945. (Jakarta: Pustaka Sinar Harapan, 1994)

[15] Agussalim Andi Gadjong, Pemerintahan Daerah: Kajian Politik dan Hukum. (Bogor: Ghalia Indonesia, 2007), p.88-89

[16] Jimly Asshiddique, Konstitusi \& Konstitusionalisme Indonesia, (Jakarta: Konstitusi Press, 2005)

[17] Koirudin, Sketsa Kebijakan Desentralisasi di Indonesia, Format Masa Depan Otonomi Menuju Kemandirian Daerah, (Malang: Averroes Press, 2005).

[18] The Liang Gie, Pertumbuhan Pemerintahan Daerah di Negara Republik Indonesia, (Yogyakarta: Liberty, 1995), p. 60.

[19] Rahardjo Adisasmita, Pembangunan Pedesaan dan Perkotaan, (Yogyakarta: Graha Ilmu, 2006), p. 70.

[20] Bohari, Pengantar Hukum Pajak,cet-8, (Jakarta: Rajawali Pers, 2010), p. 11.

[21] Op.Cit., Rahardjo Adisasmita, p. 7.

[22] Mochtar Kusumaatmadja, Konsep-konsep Hukum dalam Pembangunan, cet-4, (Bandung: Alumni, 2013), p. 89.

[23] https://kbbi.web.id/konvergensi

[24] Danrivanto Budhijanto, (2014). Teori Hukum Konvergensi, Bandung: PT Refika Aditama. p.94

[25] Anthony Ogus, "Competition Between National Legal System: A Contribution of Economic Analysis to Comparative Law", 48 Int'l \& Comp. L.Q.405 (1999); Ugo A. Mattei, Luisa Antonioli \& Andrea Rossato, "Comparative Law and Economics", 1 Encyclopedia of Law and Economics 505 (Boudewijn Bouckaert \& Gerrit De Geest eds., 2000). Jennifer G. Hill, "The Persistent Debate about Convergence in Comparative Corporate Governance", 27 Sydney L. Rev. 743 (2005). Ronald J. Gilson, "Globalizing Corporate Governance: Convergence of Form or Function", 49 Am. J. Comp. L.329 (2001). In Op.Cit., Danrivanto Budhijanto, p. viii. 
[26] Ralf Michaels, "Two Paradigm of Jurisdiction", Michigan Journal of International Law, Summer 2006. E.g., Konrad Zweigert \& Hein Kotz, Introduction to Comparative Law 24 (Tony Weir trans., 3d ed. 1998); Ugo Mattei, "A Transaction Costs Approach to the European Civil Code", 5 Eur. Rev. Priv. L. 537 (1997). In Ibid., Danrivanto Budhijanto, p. 97

[27] Pierre Legrand, "European Legal System Are Not Converging”, 45 Int'l \& Comp. L.Q. 52, 61-62 (1996). ). In Op.Cit., Danrivanto Budhijanto

[28] Op.Cit., Danrivanto Budhijanto, (2014). Teori Hukum Konvergensi, Bandung: PT Refika Aditama. P.101

[29] Nuno Garoupa dan Anthony Ogus, "A Strategic Interpretation of Legal Transplant”, Journal of Legal Studies, The University of Chicago, Juni, 2006. In Op.Cit., Danrivanto Budhijanto, p.97

[30] Ibid.

[31] James Gordley, "Is Comparative Law a Distinct Discipline?", 46 Am. J. Comp. L. 607 (1998), In Op.Cit., Danrivanto Budhijanto

[32] Nyimas Latifah Letty Aziz, dkk., Model Desentralisasi Asimetris dalam NKRI, (Jakarta: Yayasan Pustakan Obor Indonesia, 2020), p.X

[33] Wehner J, "Asymmetrical Devolution. Devolution in South Africa". In Nyimas Latifah Letty Aziz, Potret Politik Pengelolaan Dana Otonomi Khusus dan Istimewa, (Jakarta: Yayasan Pustaka Obot Indonesia, 2018), p.249

[34] R. Siti Zuhro, Otonomi Daerah dan Keindonesiaan, Jurnal Bhinneka Tunggal Ika, 2, No.2, (Jakarta: Sekjen DPD RI, 2011), p.40
[35] Op.Cit., Nyimas Latifah Letty Aziz, dkk., p.6

[36] Muhammad Habibi \& Erni Zuhriyati, Kecemburuan Daerah Penghasil Setelah Praktek Desentralisasi Asimetris, https://www.researchgate.net/publication/330424411_Kecem buruan_Daerah_Penghasil_Setelah_Praktek_Desentralisasi_A simetris

[37] A. Dwipayana \& A.E. Widiarto (Ed.), Kajian Desentralisasi Asimetris dan Otonomi Khusus di Indonesia: Studi Kasus Provinsi Bali dan Provinsi Kepulauan Riau, (Jakarta: Sekjen DPD RI, 2013).

[38] S. Parolari \& L. Voltmer, "Legislative and Administrative Autonomy", in J. Woelk, F. Palermo \& J. Marko (Eds.), Tolerance through Law: Self Governance and Group Rights in South Tyrol, (Leidern-Boston: Martinuss Nijhoff, 2008), pp. 77-103, in Op.Cit., Nyimas Latifah Letty Aziz, et al.

[39] During the two decades that Papua's special autonomy has been running, the disappointment of indigenous peoples over forest and land issues has not ended. Conflicts between communities, companies and the government occur in many places in Papua. Data from Forest Watch Indonesia, shows the rate of deforestation in Papua. In the period 2000-2009, the rate of deforestation in the Papua bioregion was 60,300 hectares per year. It tripled in the 2009-2013 period covering an area of 171,900 hectares per year. The next period, 2013-2017, the rate of deforestation also increased to 189,300 hectares per year. Candra Fajri Ananda, Asymmetric Decentralization in Indonesia, Koran SINDO, accessed on June 9, 2021, at https://nasional.sindonews.com/read/435544/18/asymmetricdecentralization-di-indonesia-1621807552 